\begin{tabular}{l|l|l} 
Jurnal Eksplorasi Akuntansi & e-ISSN : 2656-3649 (Online) \\
Vol. 3, No 3, Agustus 2021, Hal 624-639:/jea.ppj.unp.ac.id/index.php/jea/index
\end{tabular}

\title{
Pengaruh Intergovernmental Revenue, Kekayaan Daerah dan Sisa Lebih Pembiayaan Anggaran terhadap Belanja Modal (Studi Empiris pada Kabupaten/Kota di Propinsi Sumatera Barat)
}

\author{
Hikmah Fuji Astuti ${ }^{1 *}$, Erinos NR ${ }^{2}$ \\ ${ }^{1,2}$ Fakultas Ekonomi, Universitas Negeri Padang \\ *Korespondensi: hikmahfa70@gmail.com
}

\begin{abstract}
This study aims to examine the effect of intergovernmental revenue, regional wealht and financing surplus budget of capital expenditure.Population in this study were districts/cities in West Sumatera Province in 2015-2019. The analytical tool used in this study Is multiple linear regression analysis. The results of this study indicate that intergovernmental revenue and regional wealth has positive significant influence of capital expenditure. Financing surplus budget doesn't significant influence of capital expenditure.
\end{abstract}

Keywords: intergovernmental revenue; regional wealth; financing surplus budget; capital expenditure

How to cite (APA $6^{\text {th }}$ style)

Astuti, H. F., \& NR, Erinos. (2021). Pengaruh Intergovernmental Revenue, Kekayaan Daerah dan Sisa Lebih Pembiayaan Anggaran terhadap Belanja Modal (Studi Empiris pada Kabupaten/Kota di Propinsi Sumatra Barat). Jurnal Eksplorasi Akuntansi. 3(3). 624639.

\section{PENDAHULUAN}

Semenjak diberlakukannya otonomi daerah melalui Undang-Undang nomor 32 tahun 2004 tentang Pemerintah Daerah merupakan sebuah kesempatan yang sangat baik bagi Pemerintah Daerah untuk membuktikan kemampuannya dalam melaksanakan kewenangan yang menjadi hak daerah. Pemerintah daerah dalam rangka membangun daerahnya diberikan kebebasan dalam bekreasi dan berekspresi dengan tidak melanggar ketentuan hukum yaitu perundang-undangan. Otonomi daerah merupakan sebuah sistem pemerintahan desentralisasi yang dikeluarkan oleh pemerintah, dimana dalam penyelenggaraan otonomi daerah pemerintah tentu memerlukan dana yang besar dalam menjalankan roda pemerintahan.

Desentralisasi bertujuan untuk mewujudkan kesejahteraan masyarakat melalui penyediaan pelayanan publik agar lebih merata di seluruh Indonesia (Sugiyanta, 2016). Pengalokasian anggaran dalam upaya meningkatkan pelayanan publik harus lebih diperuntukkan bagi kepentingan publik yaitu seperti belanja modal. Belanja modal menurut Undang-Undang nomor 33 tahun 2004 adalah semua kewajiban daerah yang diakui sebagai pengurangan nilai kekayaan bersih dalam periode tahun anggaran yang bersangkutan.

Menurut Dewi (2006) dan Syaiful (2008) belanja modal adalah pengeluaran yang dilakukan dalam rangka pembentukan modal yang sifatnya menambah aset tetap/investaris yang memberikan manfaat lebih dari satu periode akuntansi, termasuk didalamnya adalah 
pengeluaran untuk biaya pemeliharaan yang sifatnya mempertahankan atau menambah masa manfaat, meningkatkan kapasitas dan kualitas aset. Standar Akuntansi Pemerintah (SAP) mendefinisikan pengertian belanja modal adalah pengeluaran yang dilakukan dalam rangka pembentukan modal yang sifatnya menambah aset tetap/investasi yang memberikan manfaat lebih dari satu periode akuntansi.

Alokasi belanja modal dalam APBD didasarkan pada kebutuhan daerah akan sarana dan prasarana, baik untuk kelancaran pelaksaaan tugas pemerintah maupun fasilitas publik (Abdullah dan Halim, 2006). Menurut Aprizay et al., (2014) selama ini alokasi belanja daerah lebih banyak digunakan untuk belanja pegawai dan belanja rutin yang kurang produktif dan sisanya hanya sebagian kecil untuk belanja modal. Kesimpulannya alokasi belanja modal didaerah belum sepenuhnya terlaksana dengan baik, karena pengelolaan belanja modal belum diprioritaskan untuk kebutuhan dan kesejahteraan publik.

Faktor lain yang menyebabkan realisasi belanja modal cenderung lebih lambat yaitu (1) belanja modal pada umumnya dialokasikan untuk pembangunan infrastruktur-infrastruktur yang besar, (2) peningkatan kapasitas belanja modal pada umumnya terbatas pada kementrian-kementrian dan lembaga tertentu yang memiliki tugas pokok dan fungsi pembangunan (Askolani, 2019). Pemerintah daerah di sini diharapkan dapat mengalokasikan anggaran belanja modal sesuai dengan peraturan yang telah ditetapkan supaya tidak terjadi asimetri informasi antara pemerintah pusat dengan pemerintah daerah ataupun antara masyarakat dengan pemerintah.

Intergovernmental revenue atau dana perimbangan adalah salah satu sumber penerimaan daerah yang memiliki kontribusi besar terhadap anggaran pendapatan belanja daerah. Menurut undang-undang nomor 33 tahun 2004 tentang perimbangan keuangan antara pemerintah pusat dengan pemerintah daerah, menyebutkan bahwa intergovernmental revenue adalah dana yang bersumber dari pendapatan APBN yang dialokasikan pada daerah untuk mendanai kebutuhan dalam rangka desentralisasi. Menurut Budianto dan Alexander (2016) apabila pengelolaan daerah dilakukan dengan benar sesuai dengan peraturan yang ditetapkan maka akan meningkatkan kinerja pemerintah daerah. Pemerintah Pusat mengeluarkan Undang-Undang nomor 33 tahun 2004 tentang perimbangan keuangan dimana intergovernmental revenue terdiri atas Dana Alokasi Umum (DAU), Dana Alokasi Khusus (DAK), dan Dana Bagi Hasil (DBH). Penelitian yang dilakukan oleh Rahayu (2019), Malau, Erlina \& Sirojuzilam (2019), Arifah \& Haryanto (2019), Abdullah \& Rona (2014) menyatakan bahwa dana perimbangan berpengaruh signifikan terhadap belanja modal. Penelitian ini tidak sejalan dengan penelitian yang dilakukan oleh Sari et al., (2017) yang menemukan bahwa dana perimbangan tidak berpengaruh signifikan terhadap belanja modal.

Menurut Tobu (2018) selain intergovernmental revenue, kekayaan daerah merupakan salah satu bentuk sumber penerimaan daerah yang digunakan untuk meningkatkan kesejahteraan masyarakat serta akan mempengaruhi belanja modal pemerintah. Siddi (2016) menyatakan bahwa tingkat kekayaan daerah merupakan salah satu bentuk sumber daya yang dimiliki oleh pemerintah daerah yang digunakan pemerintah untuk melaksanakan fungsi pelayanan kepada masyarakat. Daerah yang memiliki kekayaan yang besar akan mempunyai kemampuan lebih baik dalam memberikan pelayanan kepada masyarakat (Usman et al., 2019).

Kekayaan daerah yang dimiliki oleh suatu daerah harus dimanfaatkan dengan baik oleh daerah untuk meningkatkan pelayanaan, sarana, dan prasarana publik, karena untuk dapat memberikan pelayanan yang baik kepada masyarakat maka harus didukung dengan kekayaan yang dimiliki oleh pemerintah daerah tersebut (Mustikarini dan Fitriasari (2012). Sepengetahuan peneliti penelitian terdahulu masih sedikit yang meneliti tentang kekayaan daerah berpengaruh atau tidak terhadap belanja modal, karena keterbatasan peneliti dalam mencari jurnal sehingga peneliti belum menemukan jurnal tentang kekayaan daerah berpengaruh atau tidak terhadap belanja modal. Peneliti mencoba menggali lebih dalam 
tentang pengaruh kekayaan daerah terhadap belanja modal yang dilakukan pada pemerintah kabupaten/Kota di provinsi Sumatera Barat.

Sumber pendanaan lainnya untuk alokasi belanja modal yaitu Sisa Lebih Pembiayaan Anggaran (SiLPA) tahun anggaran sebelumnya. Menurut Peraturan Menteri Dalam Negeri (Pemendagri) Nomor 13 tahun 2006 Sisa lebih pembiayaan anggaran adalah selisih lebih realisasi penerimaan dan pengeluaran anggaran selama satu periode anggaran. Menurut Ardhani (2011) sisa lebih pembiayaan anggaran yang besar terjadi apabila pendapatan lebih besar dibanding belanja dan transfer. SiLPA yang besar akan menunjukkan lemahnya kinerja eksekutif dalam perencanaan dan pengelolaan dana yang ada di pemerintah daerah (Sukmawati et al., 2016). SiLPA yang besar menunjukkan kinerja pemerintah yang kurang optimal atau masih rendah, namun sisa lebih pembiayaan anggaran tersebut bisa digunakan untuk belanja daerah periode yang akan datang dan diharapkan kinerja pemerintah semakin baik juga. Penelitian yang dilakukan oleh Kusnandar \& Siswantoro (2012), Mentayani \& Rusmanto (2013), Arifah \& Haryanto (2019), Rahayu (2019), Abdullah \& Rona (2014), Fahlevi (2017), Mutiah \& Mappanyuki (2016) menemukan bahwa sisa lebih pembiayaan anggaran berpengaruh signifikan terhadap belanja modal. Sisa lebih pembiayaan anggaran merupakan salah satu dana dalam membiayai belanja modal pemerintah.

Alokasi belanja modal untuk kabupaten/kota di Provinsi Sumatera Barat dari tahun 2015-2019 masih rendah atau belum optimal.Hal ini terbukti bahwa rata-rata pengalokasian belanja modal di kabupaten/kota di Provinsi sumatera Barat dari tahun 2015-2019 masih dibawah 20\%. Menurut Amanat Peraturan Presiden nomor 5 tahun 2010 tentang RPJMN (Rencana Pembangunan Jangka Menengah Nasional) dimana secara keseluruhan jumlah belanja modal yang dialokasikan dalam APBD sekurang-kurangnya 29\% dari belanja daerah, sedangkan pada kabupaten/kota di provinsi Sumatera Barat rata-rata masih 20\%. Fenomena ini menunjukkan bahwa pemerintah daerah pada kabupaten/kota di provinsi Sumatera Barat masih sedikit menggunakan belanja modal dari belanja daerahnya.

Pemerintah daerah selama ini justru lebih banyak membuat belanja yang sifatnya birokratis dari pada belanja modal seperti menambah pegawai dan administrasi, padahal realisasi dari belanja modal sendiri akan punya daya dorong ke investasi daerah, sementara belanja-belanja yang bersifat birokratis hanya akan memberikan dampak minim ke ekonomi daerah. Hal tersebut membuat anggaran belanja modal perlu dinaikkan lagi apabila belanja pegawai masih lebih besar, karena belanja modal nantinya bisa difokuskan untuk pembangunan infrastruktur sehingga tentunya juga dapat mendorong pertumbuhan ekonomi (Simanjuntak, 2015).

Penelitian ini bertujuan untuk memberikan bukti empiris mengenai pengaruh intergovernmental revenue, kekayaan daerah dan sisa lebih pembiayaan anggaran terhadap belanja modal kabupaten/kota di Provinsi Sumatera Barat tahun 2015-2019. Hasil penelitian ini diharapkan berguna bagi pihak-pihak berkepentingan dalam pengambilan keputusan yang akan meningkatkan belanja modal pemerintah daerah

\section{LANDASAN TEORI DAN HIPOTESIS \\ Teori Keagenan (Agency Theory)}

Teori keagenan (agency theory) adalah teori yang menjelaskan hubungan antara principal (pemilik) dengan agent (manajer) dalam menjalankan suatu perusahaan. Jensen dan Meckling (1976), menyatakan bahwa hubungan keagenan merupakan sebuah persetujuan (kontrak) antara dua pihak, yaitu principal dan agent untuk mengambil keputusan atas nama principal.Teori keagenan dalam pemerintah daerah bisa dilihat dari hubungan antara pemerintahan pusat dan pemerintahan daerah, selain itu bisa dilihat juga dari hubungan antara pemerintah daerah dan masyarakat, masyarakat sebagai principal memberikan kepercayaan kepada pemerintah untuk mengelola sumber daya daerah mereka. 
Pemerintah sebagai agent yang harusnya mengelola semua sumber kekayaan daerah harus sesuai dengan semestinya. Pemerintah sudah seharusnya memberikan timbal balik kepada masyarakat dalam bentuk pelayan publik yang memadai (Aryani, 2017). Berdasarkan teori agency yang digunakan pada penelitian ini pengelolaan pemerintah daerah harus diawasi tujuan untuk memastikan bahwa pengelolaan tersebut dilakukan sesuai dengan peraturan yang telah ditetapkan.

\section{Belanja Modal}

Belanja modal menurut Undang-Undangn nomor 33 tahun 2004 adalah semua kewajiban daerah yang diakui sebagai pengurangan nilai kekayaan bersih dalam periode tahun anggaran yang bersangkutan. Alokasi belanja modal akan menunjangaktifitas masyarakat yang nantinya akan meningkatkan pertumbuhan ekonomi masyarakat. Menurut Kadafi (2013) peningkatan pertumbuhan ekonomi masyarakat tumbuh karena adanya dukungan dari fasilitas yang diberikan oleh pemerintah dari alokasi belanja modal, sehingga menarik investor luar untuk menginvestasikan dananya

\section{Intergovernmental Revenue}

Intergorvemental revenue atau dana perimbangan adalah salah satu sumber penerimaan daerah yang memiliki kontribusi besar terhadap anggaran pendapatan belanja daerah. Peraturan Pemerintah nomor 55 tahun 2005 mendefinisikan bahwaintergovernmental revenue adalah dana yang bersumber dari pendapatan APBN yang dialokasikan kepada daerah untuk mendanai kebutuhan daerah dalam rangka pelaksanaan desentralisasi. Dana perimbangan berupa investasi yang dilakukan oleh pemerintah pusat kepada pemerintah daerah untuk pembangunan daerah dan peningkatan layanan publik.

\section{Kekayaan Daerah}

Menurut Siddi (2016) kekayaan daerah merupakan suatu bentuk sumber daya yang dimiliki oleh pemerintah daerah yang digunakan pemerintah untuk melaksanakan fungsi pelayanan kepada masyarakat. Kekayaan daerah akan menggambarkan pendapatan yang berasal dari daerah itu sendiri dan dapat menggambarkan mandiri atau tidaknya daerah itu dalam membiayai pengeluaran daerahnya. Kekayaan daerah berbanding lurus dengan tingkat kepedulian yang dimiliki masyarakat kepada pemerintah daerah, sehingga semakin besar kekayaan daerah maka semakin besar juga kepedulian masyarakat terhadap pengeloaan kekayaan tersebut oleh pemerintah (Afriansyah, 2013).

\section{Sisa Lebih Pembiayaan Anggaran}

Standar akuntansi pemerintah (SAP) nomor 02 menyatakan bahwa Sisa Lebih Pembiayaan Anggaran (SILPA) adalah sisa lebih antara realisasi penerimaan dan pengeluaran selama satu periode pelaporan. Sisa lebih pembiayaan anggaran adalah selisih lebih realisasi penerimaan dan pengeluaran anggaran selama satu periode anggaran (Mentayani dan Rusmanto, 2013). SiLPA yang besar akan menunjukan lemahnya kinerja eksekutif dalam perencanaan dan pengelolaan dana yang ada di pemerintah daerah. SiLPA digunakan oleh pemerintah daerah kebanyakan dalam membiayai belanja langsung seperti belaja modal yang secara langsung memenuhi kebutuhan masyarakat. Belanja langsung bisa digunakan untuk pembangunan infastruskur, pengadaan aset dan sebagainya yang didalamnya juga terdapat belanja tidak langsung (Adriani dalam Mentani dan Rusmanto, 2013).

\section{Pengaruh Intergovrenmental Revenue Terhadap Belanja Modal}


Intergovernmental revenue atau dana perimbangan adalah salah satu sumber dana dalam membiayai belanja modal daerah. Intergovernmental revenue bersumber dari dana APBN yang dialokasikan kepada pemerintah daerah untuk mendanai kebutuhan daerah seperti pembangunan dan peningkatan pelayanan publik yang merupakan pengeluaran dari belanja modal. Hubungan antara intergovernmental revenue terhadap belanja modal dapat dilihat dari teori keagenan yang menjelaskan hubungan antara principal dan agent (dilihat dari hubungan pemerintah pusat dengan pemerintah daerah). Pemerintah pusat dalam mendanai kebutuhan daerah seperti pembangunan, pemerintah daerah mendapatkan porsi transfer dana dari pemerintah pusat dalam bentuk dana perimbangan. Transfer dana dari pemerintah pusat tersebut diharapkan mampu membiayai belanja pemerintah.

Penelitian yang dilakukan oleh Rahayu (2019), Malau, Erlina \& Sirojuzilam (2019), Arifah \& Haryanto (2019), Abdullah \& Rona (2014) menyatakan bahwa dana perimbangan berpengaruh signifikan terhadap belanja modal. Pemerintah daerah berarti masih memiliki ketergantungan terhadap dana perimbangan dalam membiayai belanja modalnya. Berdasarkan penjelasan tersebut maka hipotetsis pertama yang diajukan adalah:

H1: Intergovernmental revenue berpengaruh positif terhadap belanja modal

\section{Pengaruh Kekayaan Daerah Terhadap Belanja Modal}

Tingkat kekayaan daerah merupakan suatu bentuk sumber daya yang dimiliki oleh pemerintahan daerah yang digunakan pemerintah untuk melaksanakan fungsi pelayanan kepada masyarakat. Kekayaan daerah yang dimiliki oleh suatu daerah harus dimanfaatkan dengan baik oleh daerah untuk meningkatkan pelayanaan, sarana, dan prasarana publik. Hubungan antara kekayaan daerah terhadap belanja modal dapat dilihat dari teori keagenan yaitu hubungan antara principal dan agent. Masyarakat sebagai principal membutuhkan sarana dan prasarana serta pelayanan dari pemerintah (agent).Pemerintah dalam memberikan pelayanan yang baik kepada masyarakat maka harus didukung dengan kekayaan yang dimiliki oleh pemerintah daerah tersebut (Mustikarini dan Fitriasari (2012). Daerah yang memiliki kekayaan yang besar akan memiliki kemampuan yang lebih baik dalam memberikan pelayanan kepada masyarakat.

Kekayaan daerah pada penelitian ini dilihat dari total aset yang dimiliki oleh daerah. Kekayaan daerah yang dilihat dari total aset terhadap belanja modal memiliki hubungan yang positif, karena besar atau kecilnya total aset pada suatu pemerintah daerah bisa mempengaruhi daerah dalam mengambil keputusan penentuan belanja modalnya (Rudsan, 2016). Penelitian yang dilakukan oleh Widiasmara (2019) menemukan bahwa Total Asset berpengaruh signifikan terhadap belanja modal. Pemerintah daerah disini masih memiliki ketergantungan terhadap total asset dalam membiayai belanja modalnya. Berdasarkan penjelasan tersebut maka hipotetsis kedua yang diajukan adalah:

H2: Kekayaan daerah berpengaruh positif terhadap belanja modal

\section{Pengaruh Sisa Lebih Pembiayaan Anggaran (SiLPA) terhadap Belanja Modal}

Sisa lebih pembiayaan anggaran adalah selisih lebih realisasi penerimaan dan pengeluaran anggaran selama satu periode anggaran (Mentayani dan Rusmanto, 2013). Menurut Sukmawati et al., (2016) SiLPA yang besar akan menunjukkan lemahnya kinerja eksekutif dalam perencanaan dan pengelolaan dana yang ada di pemerintah daerah. SiLPA yang besar menunjukkan kinerja pemerintah yang kurang optimal atau masih rendah, namun sisa lebih pembiayaan anggaran tersebut bisa digunakan untuk belanja daerah periode yang akan datang dan diharapkan kinerja pemerintah semakin baik juga. Sisa lebih pembiayaan anggaran bisa digunakan oleh pemerintah daerah dalam membiayai belanja modal dari pemerintah daerah tersebut. 
Dana sisa lebih perhitungan anggaran dapat digunakan oleh pemerintah untuk pembangunan infrastruktur dalam bentuk belanja modal. Penelitian yang dilakukan oleh Kusnandar \& Siswantoro (2012), Mentayani \& Rusmanto (2013), Arifah \& Haryanto (2019), Rahayu (2019), Abdullah \& Rona (2014), Fahlevi (2017), Mutiah \& Mappanyuki (2016) menemukan bahwa sisa lebih pembiayaan anggaran berpengaruh signifikan terhadap belanja modal. Sisa lebih pembiayaan anggaran berarti masih memiliki peran dalam membiayai belaja modal pemerintah daerah. Berdasarkan penjelasan tersebut hipotetsis ketiga yang diajukan adalah:

H3: Sisa Lebih Pembiayaan Anggaran berpengaruh positif terhadap belanja modal

\section{METODE PENELITIAN}

\section{Populasi dan Sampel Penelitian}

Populasi dalam penelitian ini adalah sembilan belas (19) kabupaten/kota yang ada di provinsi Sumatera Barat. Pemilihan sampel dalam penelitian ini menggunakan total sampling, yaitu semua anggota populasi mempunyai peluang untuk dipilih menjadi anggota sampel. Sampel dalam penelitian ini berjumlah 95 sampel yang di ambil dari laporan realisasi anggaran, neraca dan evaluasi kinerja penyelenggaraan pemerintah daerah (EKPPD) kabupaten/kota di provinsi Sumatera Barat dari tahun 2015 sampai tahun 2019.

\section{Jenis, Sumber dan Teknik Pengumpulan Data}

Jenis data yang digunakan dalam penelitian ini adalah data sekunder, yaitu data yang diperoleh, dikumpulkan dan diolah terlebih dahulu oleh pihak lain. Sumber data dalam penelitian ini adalah Laporan Realisasi Anggaran dan Neraca kabupaten/kota provinsi Sumatera Barat yang sudah di audit dan evaluasi kinerja penyelenggaraan pemerintah daerah (EKKPD) kabupaten/kota provinsi Sumatera Barat. Data diperoleh dari situs resmi Badan Pemeriksa Keuangan (BPK) Perwakilan Sumatera Barat (https://sumbar.bpk.go.id). Penelitian ini menggunakan teknik dokumentasi.

\section{VARIABEL PENELITIAN DAN PENGUKURAN \\ Belanja Modal}

Variabel dependen adalah variabel yang diakibatkan atau dipengaruhi oleh variabel bebas (Martono, 2015:360).Penelitian ini menggunakan Belanja Modal sebagai variabel Dependen (Y).Belanja Modal merupakan semua kewajiban daerah yang di akui sebagai pengurangan nilai kekayaan bersih dalam periode tahun anggaran yang bersangkutan. Pengukuran variabel belanja modal dilihat pada laporan keuangan Realisasi Anggaran Pemerintah Daerah Kabupaten/Kota Provinsi Sumatera Barat yang sudah diaudit. Belanja modal diukur dengan menggunakan Logaritma Natural (Ln) belanja modal yang dimiliki oleh pemerintah daerah untuk menghindari data yang tidak normal, dengan menggunakan rumus:

Belanja Modal $=$ Ln (belanja tanah + belanja peralatan tanah dan mesin + belanja gedung dan bangunan + belanja jalan, irigasi dan jaringan + belanja aset tetap lainnya).

\section{Intergovrenmental Revenue}

Intergovernmental revenue (X1), merupakan dana yang bersumber dari pendapatan APBN yang di alokasikan kepada daerah untuk mendanai kebutuhan daerah dalam rangka pelaksanaan desentralisasi. Pengukuran variabel intergovernmental revenue dilihat pada laporan keuangan Realisasi Anggaran Pemerintah Daerah Kabupaten/Kota di provinsi Sumatera Barat yang sudah diaudit. Intergovernmental revenue diukur dengan menggunakan logaritma natural (Ln) dana perimbangan yang dimiliki oleh pemerintah daerah untuk menghindari data yang tidak normal, dengan menggunakan rumus: 
Intergovernmental Revenue $=$ Ln $($ Dana Alokasi Umum + Dana Alokasi Khusus + Dana Bagi Hasil).

\section{Kekayaan Daerah}

Kekayaan daerah (X2), merupakan suatu bentuk sumber daya yang dimiliki oleh pemerintah daerah yang digunakan pemerintah untuk melaksanakan fungsi pelayanan kepada masyarakat. Kekayaan daerah dalam penelitian ini diukur menggunakan total aset, ini sejalan dengan Armaja et al., (2015) yang menyatakan bahwa kekayaan daerah dapat diukur dengan menggunakan total aset yang dimiliki oleh daerah tersebut. Total aset adalah seluruh kekayaan sumber daya yang dimiliki oleh entitas bisnis yang diukur secara jelas menggunakan satuan uang serta sistem pengukuran berdasarkan pada seberapa cepat perubahannya dikonversi menjadi satuan uang kas. Total aset yang besar diharapkan dapat memberikan kemudahan operasional dan pelayanan yang memadai kepada masyarakat. Total aset besar atau kecil pada suatu pemerintah daerah bisa mempengaruhi daerah dalam mengambil keputusan penentuan belanja modalnya (Rudsan, 2016).

Kekayaan daerah dalam penelitian ini diukur dengan melihat total aset yang dimiliki oleh pemerintah daerah denganmenggunakan logaritma natural ( $\mathrm{Ln}$ ) untuk menghindari data yang tidak normal. Total aset yang ada di pemerintah daerah dapat menggambarkan seberapa besar kekayaan daerah yang bisa dilihat dari besarnya sumber daya yang dimiliki oleh daerah tersebut. Pengukuran variabel dilihat pada Neraca Pemerintah Daerah Kabupaten/Kota Provinsi Sumatera Barat yang sudah diaudit, dengan menggunakan rumus:

$$
\text { Kekayaan Daerah }=\text { Ln }(\text { Total aset })
$$

\section{Sisa Lebih Pembiayaan Anggaran}

Sisa Lebih Pembiayaan Anggaran (X3), merupakan selisih lebih realisasi penerimaan dan pengeluaran anggaran selama satu periode anggaran. Pengukuran variabel sisa lebih pembiayaan dilihat pada laporan keuangan Realisasi Anggaran Pemerintah Daerah Kabupaten/Kota di provinsi Sumatera Barat yang sudah diaudit. Sisa lebih pembiayaan anggaran dalam penelitian ini diukur dengan menggunakan logaritma natural (Ln) SiLPA yang dimiliki oleh pemerintah daerah untuk menghindari data yang tidak normal, dengan menggunakan rumus:

Sisa Lebih Pembiayaan Anggaran = Ln (Surplus/defisit Realisasi Anggaran + Pembiayaan Netto).

\section{Metode Analisis Data}

Analisis data pada penelitian ini diuji menggunakan program SPSS 22 dengan menggunakan model regresi linear berganda dengan persamaan:

$$
\mathrm{Y}=\alpha+\beta 1 \mathrm{IR}+\beta 2 \mathrm{KD}+\beta 3 \operatorname{SiLPA}+\mathrm{e}
$$

Keterangan:

$$
\begin{array}{ll}
\mathrm{BM} & =\text { Belanja Modal } \\
\alpha & =\text { Konstanta } \\
\beta 1 \mathrm{IR} & =\text { Koefisien Regresi dari Intergovernmental Revenue } \\
\beta 2 \mathrm{KD} & =\text { Koefisien Regresi dari x2 Kekayaan Daerah } \\
\beta 3 \mathrm{SiLPA} & =\text { Koefisien Regresi dari Sisa Lebih Pembiayaan Anggaran } \\
\mathrm{e} & =\text { error }
\end{array}
$$




\section{Tabel 1}

Hasil Analisis Statistik Deskriptif

\begin{tabular}{lrrrrr}
\hline & \multicolumn{5}{c}{ Descriptive Statistics } \\
& $\mathrm{N}$ & Minimum & Maximum & Mean & Std. Deviation \\
\hline Intergovernmental Revenue & 81 & 26,67 & 27,99 & 27,3601 &, 29427 \\
Kekayaan Daerah & 81 & 27,27 & 29,59 & 28,0598 &, 31940 \\
Sisa Lebih Pembiayaan & 81 & 23,19 & 25,96 & 24,9065 &, 64927 \\
$\begin{array}{l}\text { Anggaran } \\
\text { Belanja Modal }\end{array}$ & 81 & 25,27 & 26,76 & 26,0390 &, 28890 \\
$\quad$ Valid N (listwise) & & & & & \\
\hline
\end{tabular}

Hasil uji statistik deskriptif terhadap belanja modal menunjukan nilai minimum 25,27 dan nilai maksimum 26,76 dengan nilai rata-rata 26,0390 dan standar deviasi 0,28890. Variabel independen pertama pada penelitian ini adalah intergovernmental revenue. Hasil uji statistik deskriptif terhadap intergovernmental revenue menunjukan nilai minimum 26,67 dan nilai maksimum 287,99 dengan nilai rata-rata 27,3601 dan standar deviasi 0,29427.Variabel independen kedua pada peelitian ini adalah kekayaan daerah. Hasil uji statistik deskriptif terhadap kekayaan daerah menunjukan nilai minimum 27,27 dan nilai maksimum 29,59 dengan nilai rata-rata 28,0598 dan standar deviasi 0,31940. Variabel independen ketiga pada penelitian ini adalah sisa lebih pembiayaan anggaran. Hasil uji statistik deskriptif terhadap kompleksitas pemerintah menunjukan nilai minimum 23,19 dan nilai maksimum 25,96 dengan nilai rata-rata 24,9065 dan standar deviasi 0,28890 .

\section{UJI ASUMSI KLASIK \\ Uji Normalitas}

Tabel 2

Hasil Uji Normalitas (One-SampleKolmogorof-SmirnofTest)

One-SampleKolmogorov-SmirnovTest

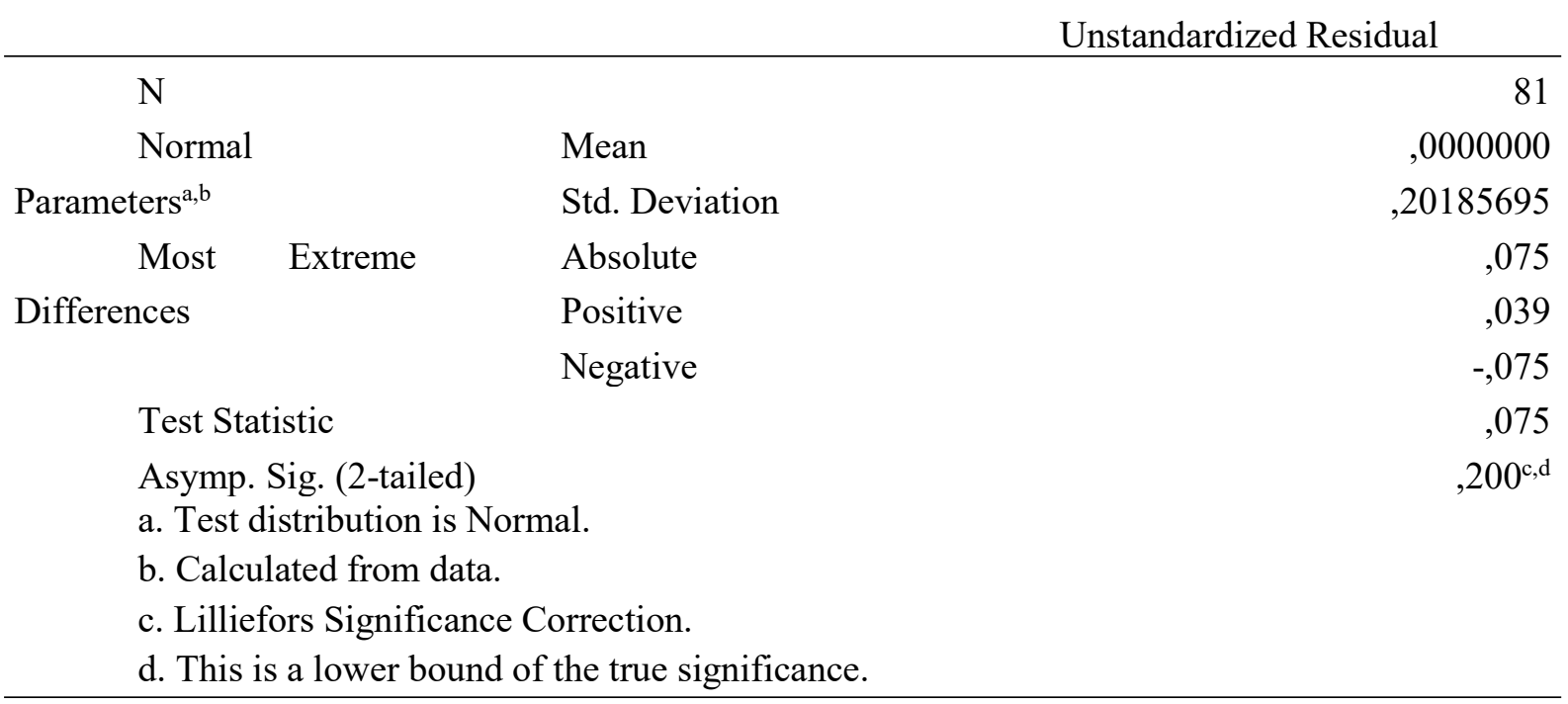

Sumber: Data Olahan SPSS 22, Tahun 2020

Tabel di atas menunjukan hasil uji normalitas dengan One-Sample KolmogorofSmirnov Test. Hasil uji normalitas pada penelitian ini memiliki probabilitas tingkat signifikasi 
0,20 di atas nilai signifikasi kepercayaan 0,05 , Ini berarti data penelitian ini berdistribusi secara normal.

\section{Uji Multikolonioritas}

Tabel 3

Hasil Uji Multikolineoritas

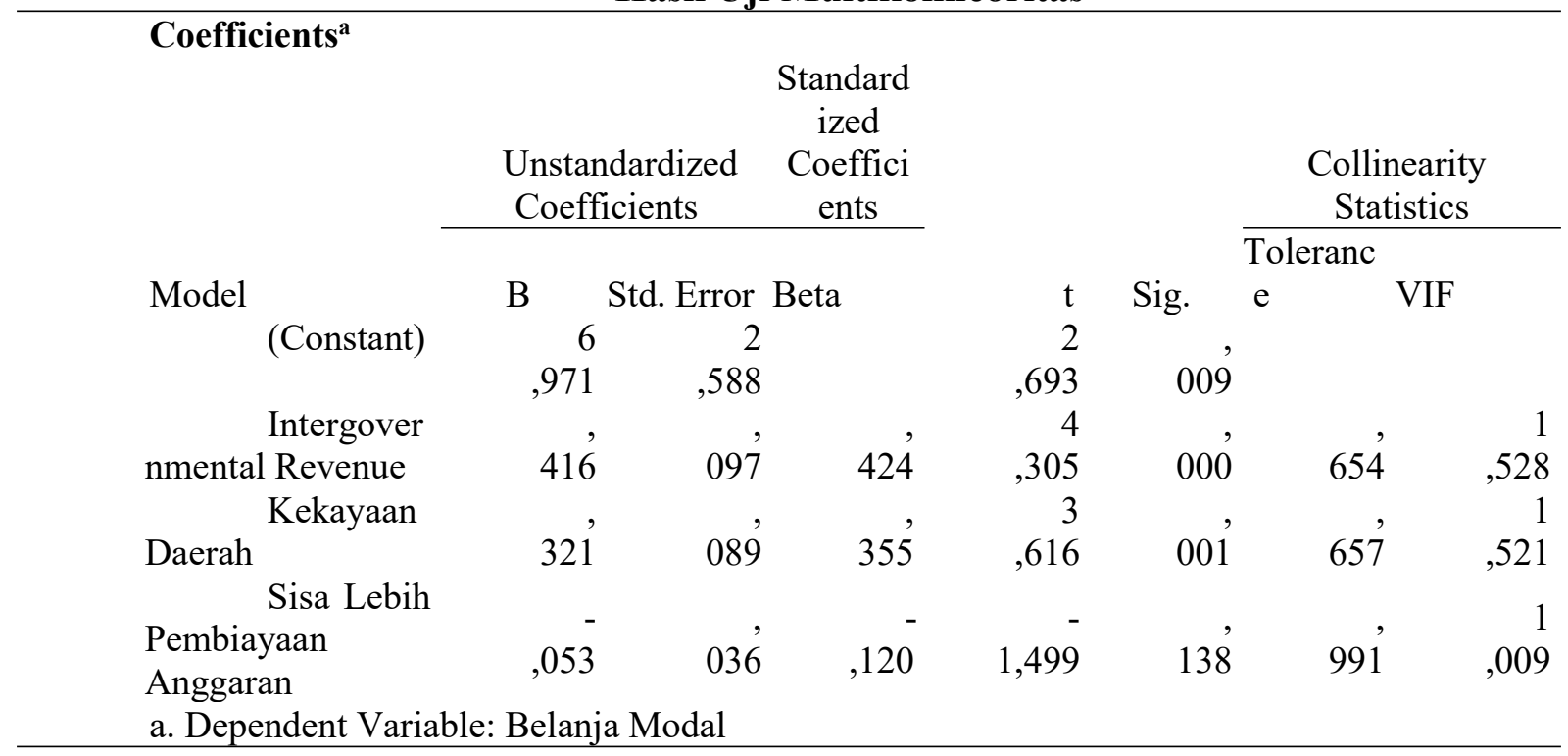

Sumber: Data Olahan SPSS 22, Tahun 2020

Berdasarkan tabel diatas tidak ada variabel bebas yang memiliki nilai tolerance kurang dar 0,10. Hasil perhitungan VIF juga menunjukan hal yang sama yaitu tidak ada satupun variabel bebas yang memiliki nilai VIF lebih besar dari 10. Sehingga disimpulkan bahwa tidak terjadi multikolineoritas pada variabel bebas dalam penelitian ini.

\section{Uji Autokorelasi}

Tabel 4

Hasil Uji Autokorelasi

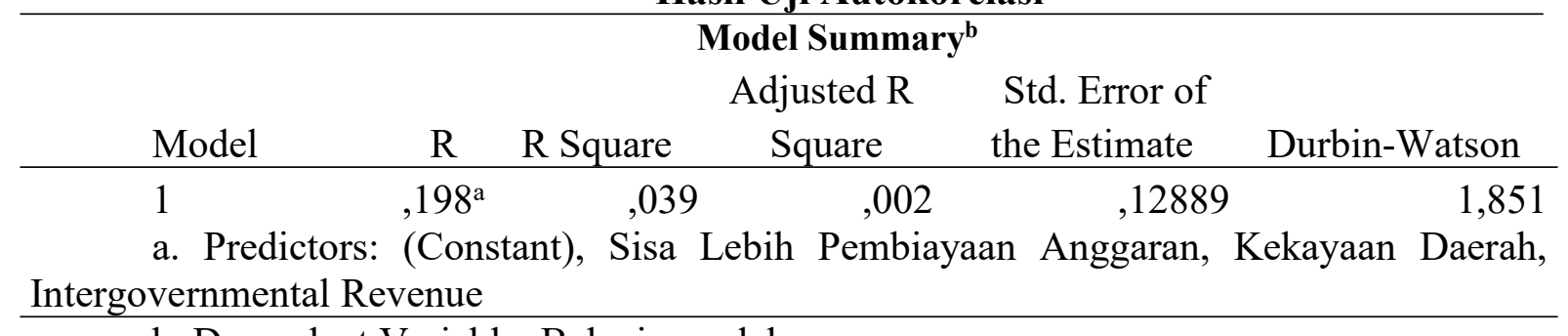

b. Dependent Variable: Belanja modal

Sumber: Data Olahan SPSS 22, Tahun 2020

Tabel 4 diatas menunjukkan bahwa nilai DurbinWatson (DW) adalah sebesar 1,851, yang berarti berada diantara dU sebesar 1.7164 dan 4-dU sebesar 2.2836 maka dapat dikatakan bahwa model regresi ini tidak mengandung masalah autokorelasi.

\section{Uji Heterokodestisitas}

\section{Tabel 5}




\section{Coefficients}

Unstandardized Standardized

Coefficients Coefficients

Std

Model

(Constant)

$\begin{array}{crr}\text { B } & \text {. Error } & \text { Bet } \\ 2 & 1,6 & \end{array}$

Beta

$$
1, \quad, 0
$$

, $867 \quad 21$

$768 \quad 81$

tal Revenue

Intergovernmen

038

, 06

$-, 087$

, 5

\section{Kekayaan}

Daerah

$$
\text { Sisa Lebih }
$$

Pembiayaan Anggaran

a. Dependent Variable: Belanja modal

$\begin{array}{rr}- & , 05 \\ , 035 & 6 \\ - & , 02\end{array}$

, 05

2

2

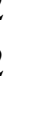

\section{Sumber: Data Olahan SPSS 22, Tahun 2020}

Tabel 5 di atas menunjukkan bahwa nilai signifikan intergovernemental revenue, kekayaan daerah dan sisa lebih pembiayaan anggaran lebih besar dari 0,05. Hasil tersebut dapat disimpulkan bahwa model regresi tidak terdapat gejala heteroskedetisitas.

\section{UJI KELAYAKAN MODEL/PENGUJIAN HIPOTESIS}

\section{Uji Statistik F}

Tabel 6

Uji Statistik F

ANOVA $^{\mathrm{a}}$

\begin{tabular}{|rr|r|r|r|r|r|}
\hline Model & & Sum of & & Mean & & F \\
Squares & Df & Square & Sig. \\
\hline 1 on & Regressi & 3,41 & 3 & 1,13 & 26,90 &, 00 \\
& & 7 & 9 & 7 & $0^{\mathrm{b}}$ \\
& Residual & 3,26 & 7 &, 042 & & \\
& & 0 & 7 & & & \\
& Total & 6,67 & 8 & & & \\
& & 7 & 0 & & & \\
& & & & & & \\
\end{tabular}

a. Dependent Variable: Belanja Modal

b. Predictors: (Constant), Sisa Lebih Pembiayaan Anggaran, Kekayaan Daerah , Intergovernmental Revenue

Sumber:Data Olahan SPSS 22, Tahun 2020

Tabel 6 di atas menunjukkan bahwa nilai signifikan hasil uji $\mathrm{F}$ adalah sebesar 0,000 , berarti $0,000<0,005$ menunjukkan bahwa secara bersama-sama pengaruh intergovernmental revenue (X1), kekayaan daerah (X2) dan sisa lebih pembiayaan anggaran (X3) berpengaruh terhadap belanja modal (Y). 


\title{
Uji Signifikasi Parameter Individual (Uji Statistik t)
}

Tabel 7

Hasil Uji Signifikasi Parameter Individual (Uji Statistik t)

\section{Coefficients $^{\mathrm{a}}$}

\author{
Unstandardized Standardi \\ Coefficients zed Coefficients
}

Std $\quad \mathrm{Si}$

\begin{tabular}{lrrrrr} 
Model & \multicolumn{1}{c}{ B } & . Error & Beta & \multicolumn{1}{c}{ T } & g. \\
\hline (Constant) & 6,9 & 2,5 & & 2,6 &, 0 \\
& 71 & 88 & & 93 & 09 \\
$\quad$ Intergovernm &, 41 &, 09 & & 4,3 &, 0 \\
ental Revenue & 6 & 7 &, 424 & 05 & 00 \\
$\quad$ Kekayaan &, 32 &, 08 & & 3,6 &, 0 \\
Daerah & 1 & 9 & & 16 & 01 \\
$\quad$ Sisa Lebih & - &, 03 & & - &, 1 \\
Pembiayaan &, 053 & 6 & & 1,499 & 38 \\
Anggaran & & & & & \\
a. Dependent Variable: Belanja Modal & & & &
\end{tabular}

Sumber:Data Olahan SPSS 22, Tahun 2020

Berdasarkan hasil olahan data statistik, maka dapat diketahui pengaruh antara variabel independen terhadap variabel dependen secara parsial sebagai berikut:

1. Hipotesis pertama dalam penelitian ini adalah intergovernmental revenue berpengaruh positif terhadap belanja modal. Data dari tabel di atas, diketahui nilai signifikan $0,000<$ 0,05 dengan Thitung 4,305 > Ttabel 1,989 yang menunjukkan bahwa intergovernmental revenue berpengaruh signifikan terhadap belanja modal, sehingga dapat disimpulkan bahwa hipotesis 1 diterima.

2. Hipotesis kedua dalam penelitian ini adalah kekayaan daerah berpengaruh positif terhadap belanja modal. Data dari tabel di atas, diketahui nilai signifikan 0,001 $<0,05$ dengan Thitung 3,616 > Ttabel 1,989 yang menunjukkan bahwa kekayaan daerah berpengaruh signifikan terhadap belanja modal, sehingga dapat disimpulkan bahwa hipotesis 2 diterima.

3. Hipotesis ketiga dalam penelitian ini adalah sisa lebih pembiayaan anggaran berpengaruh Positif terhadap belanja modal. Data dari tabel diatas, diketahui nilai signifikan 0,138> 0,05 dengan Thitung (negatif) $-1,499<$ Ttabel1,989 menunjukkan bahwa sisa lebih pembiayaan anggaran tidak berpengaruhsignifikan terhadap belanja modal, sehingga dapat disimpulkan bahwa hipotesis 3 ditolak. 
Uji Koefesien Determinasi (R-Square)

Tabel 8

Uji Koefisien Determinasi (Adjusted R-Square)

Model Summary

\begin{tabular}{|c|c|c|c|c|}
\hline Model & $\mathrm{R}$ & R Square & Adjusted R Square & Std. Error of the Estimate \\
\hline 1 & $\begin{array}{l}, 19 \\
\text { Q }\end{array}$ &, 03 &, 002 & , 12889 \\
\hline
\end{tabular}

a. Predictors: (Constant), Sisa Lebih Pembiayaan Anggaran, Kekayaan Daerah, Intergovernmental Revenue

b. Dependent Variable: Belanja modal

Sumber: Data Olahan SPSS 22, Tahun 2020

Tabel 8 di atas menunjukkan bahwa nilai R-square $\left(\mathrm{R}^{2}\right)$ sebesar 0,002 atau $0,2 \%$, artinya variabel dependen belanja modal dapat dijelaskan secara signifikan oleh variabel independen intergovernmental revenue, kekayaan daerah dan sisa lebih pembiayaan anggaran sebesar $0,2 \%$. Sisanya sebesar $99,8 \%$ dijelaskan oleh variabel lain yang tidak diamati dalam penelitian ini.

Pengaruh Intergovernmental Revenue, Kekayaan Daerah dan Sisa Lebih Pembiayaan Anggaran terhadap Belanja Modal

Bukti empiris ditemukan dalam penelitian ini bahwa secara simultan intergovernmentalrevenue, kekayaan daerah dan sisa lebih pembiayaan anggaran mempengaruhi belanja modal. Hasil tersebut dilihat melalui nilai Adjusted R-Squared. Adjusted $R$-Squared atau uji simultan menunjukkan nilai 0,002 atau $0,2 \%$ yang memiliki arti bahwa intergovernmental revenue, kekayaan daerah dan sisa lebih pembiayaan anggaran secara simultan mempengaruhi belanja modal sebesar $0,2 \%$ yang bisa dikategorikan sangat rendah sekali dan sisa 99,8\% lagi dipengaruhi oleh variabel-variabel lain diluar penelitian ini.

Berdasarkan hasil olahan data statistik yang dilihat dari Unstandarized Coefficients intergovernmental revenue memiliki nilai Beta (B) sebesar 0,416 atau 41,6\% yang memiliki arti bahwa intergovernmental revenue mempengaruhi belanja modal sebesar $41,6 \%$ yang bisa dikategorikan rendah. Kekayaan daerah memiliki nilai Beta (B) sebesar 0,321 atau 32,1\% yang memiliki arti bahwa kekayaan daerah mempengaruhi belanja modal sebesar 32,1\% yang juga bisa dikategorikan rendah, sedangkan sisa lebih pembiayaan anggaran memiliki nilai Beta (B) negatif sebesar $-0,053$ atau $-5,3 \%$ yang memiliki arti bahwa sisa lebih pembiayaan anggaran tidak mempengaruhi belanja modal.

\section{PEMBAHASAN}

\section{Pengaruh Intergovernmental Revenue terhadap Belanja Modal}

Berdasarkan pengujian yang dilakukan pada Pemerintah Kabupaten/Kota di Provinsi Sumatera Barat menunjukkan hasil analisis statistik bahwasannya intergovernmental Revenue memiliki pengaruh positif terhadap belanja modal. Keadaan ini memberikan indikasi bahwasannya semakin tinggi intergovernmental revenue yang diterima oleh pemerintah provinsi maka penggunaan terhadap belanja modal akan semakin meningkat, begitu sebaliknya jika semakin rendah intergovernmental revenue yang diterima maka penggunaan terhadap belanja modal akan semakin rendah juga, hal ini juga disebabkan karena sejak tahun 2015 sampai tahun 2019 intergovernmental revenue dialokasikan oleh pemerintah pusat 
kesetiap pemerintah provinsi secara merata, adanya intergovernmental revenue seharusnya dapat membantu belanja modal pemerintah daerah.

Intergovernmental revenue berpengaruh positif terhadap belanja modal pada Pemerintah Kabupaten/Kota di provinsi Sumatera Barat maka pemerintah bisa lebih baik dalam mengatur dana perimbangan untuk belanja modal di daerahnya, salah satunya dengan cara mendanai kebutuhan daerah seperti pembangunan dan peningkatan pelayanan publik yang merupakan bagian dari belanja modal, pemerintah daerah dapat menggunakan intergovernmental revenue pada belanja modal agar belanja modal semakin baik atau meningkat.

Hasil penelitian ini konsisten dengan penelitian yang dilakukan oleh Arifah \& Haryanto (2019), Fahlevi (2017) dan Sugiyanta (2016) yang menemukan bahwa intergovernmental revenue berpengaruh positif terhadap belanja modal, namun hasil penelitian ini bertolak belakang dengan penelitian yang dilakukan oleh Dewi \& Dicriyani (2018) yang menemukan bahwa intergovernmental revenue tidak berpengaruh terhadap belanja modal.

\section{Pengaruh Kekayaan Daerah terhadap Belanja modal}

Berdasarkan pengujian yang dilakukan pada Pemerintah Kabupaten/Kota di provinsi Sumatera Barat menunjukkan hasil analisis statistik bahwasannyakekayaan daerah memiliki pengaruh positif terhadap belanja modal. Keadaan ini memberikan indikasi bahwasannya apabila kekayaan daerah mengalami peningkatan maka belanja modal akan mengalami peningkatan juga, hal tersebut bisa menjadi pedoman bagi pemerintah daerah untuk lebih meningkatakan belanja modal, salah satunya dengan cara pemerintah daerah menggunakan kekayaan daerah yang ada pada suatu daerah tersebut dengan sebaik-baiknya untuk memenuhi kebutuhan belanja modal agar masyarakat merasa puas dengan pelayanan yang diberikan oleh pemerintah daerah, apabila masyarakat puas dengan pelayanan yang diberikan oleh pemerintah maka akan mendorong masyarakat juga untuk memenuhi kewajibannya seperti pembayaran pajak yang hal tersebut bisa menjadi pendapatan dan menambah kekayaan daerah yang ada pada suatu daerah.

Hasil penelitian ini belum ada mendukung dari penelitian terdahulu, karena keterbatasan pengetahuan peneliti dalam mencari jurnal sehingga peneliti belum menemukan jurnal yang meneliti tentang pengaruh kekayaan daerah terhadap belanja modal.

\section{Pengaruh Sisa Lebih Pembiayaan Anggaran terhadap Belanja Modal}

Berdasarkan pengujian yang dilakukan pada Pemerintah Kabupaten/Kota di provinsi Sumatera Barat menunjukkan hasil analisis statistik bahwasannya sisa lebih pembiayaan anggaran tidak berpengaruh signifikan terhadap belanja modal. Hasil ini menunjukkan bahwa sisa lebih pembiayaan anggaran pada Pemerintah Kabupaten/Kota di provinsi Sumatera Barat belum baik dalam mengalokasikan sisa pembiayaan anggaran tersebut. Semakin besar sisa lebih pembiayaan anggaran yang dihasilkan maka belanja modal semakin rendah, hal tersebut mungkin karena perolehan sisa lebih pembiayaan anggaran pada umumnya lebih rendah dibandingkan jumlah realisasi belanja modal atau karena peningkatan sisa lebih pembiayaan anggaran tidak sebanding dengan peningkatan belanja modal.

Pemerintah daerah seharusnya bisa mengalokasikan sisa lebih pembiayaan anggaran untuk mendanai kegiatan lanjutan atas belanja modal pemerintah daerah dan sebaiknya pemerintah daerah juga memperhatikan, apabila belanja modal daerah mengalami peningkatan maka penggunaan sisa lebih pembiayaan anggaran juga lebih ditingkatkan. Penelitian ini sejalan dengan penelitian yang dilakukan oleh Sukarno, Hadioetomo \& Haryadi (2019), Dewi \& Dicriyani (2018) yang menemukan bahwa sisa lebih pembiayaan anggaran tidak berpengaruh terhadap belanja modal, namun hasil penelitian ini bertolak belakang 
dengan penelitian yang dilakukan oleh Arifah \& Haryanto (2019), Fahlevi (2017) dan Sugiyanta (2016) yang menemukan bahwa sisa lebih pembiayaan anggaran berpengaruh signifikan terhadap belanja modal.

\section{SIMPULAN, KETERBATASAN DAN SARAN \\ Kesimpulan}

Penelitian ini bertujuan untuk mengetahui pengaruh intergovernmental revenue, kekayaan daerah dan sisa lebih pembiayaan anggaran terhadap belanja modal Kabupaten/Kota Provinsi Sumatera Barat tahun 2015-2019. Bukti empiris ditemukan dalam penelitian ini bahwa intergovernmental revenue, kekayaan daerah dan sisa lebih pembiayaan anggaran mempengaruhi belanja modal sangat rendah sekali, hal tersebut karena ada variabel lain yang lebih mempengaruhi belanja modal diluar penelitian ini seperti Pendapatan Asli Daerah (PAD), luas wilayah, dan investasi.

Pengaruh intergovernmental revenue, kekayaan daerah dan sisa lebih pembiayaan anggaran terhadap belanja modal dianalisis secara parsial ditemukan hasil sebagai berikut:

1. Intergovernmental revenue berpengaruh positif terhadap belanja modal. Hasil ini sejalan dengan penelitian yang dilakukan oleh Arifah \& Haryanto (2019), Fahlevi (2017) dan Sugiyanta (2016).

2. Kekayaan daerah yang diukur dengan menggunakan total aset daerahberpengaruh terhadap belanja modal. Hasil ini belum ada sejalan dengan penelitian terdahulu karena keterbatasan peneliti dalam mencari jurnal, sehingga peneliti belum menemukan jurnal yang meneliti tentang kekayaan daerah berpengaruh atau tidak terhadap belanja modal.

3. Sisa lebih pembiayaan anggaran berpengaruh negatif terhadap belanja modal. Penelitian ini sejalan dengan penelitian yang dilakukan oleh Sukarno, Hadioetomo \& Haryadi (2019) dan Dewi \& Dicriyani (2018).

\section{Keterbatasan}

Penelitian ini telah dirancang dan dilaksanakan dengan sebaik-baiknya, namun peneliti menyadari bahwa masih terdapat keterbatasan dalam penelitian ini yaitu:

1. Penelitian ini hanya dilakukan di kabupaten/kota di provinsi Sumatera Barat dari periode waktu 2015-2019 dan ini menyebabkan hasil penelitian akan berbeda jika dilakukan di daerah lain mengingat perbedaan karakteristik masing-masing wilayah di Indonesia.

2. Penelitian ini hanya menggunakan data sekunder dari laporan keuangan daerah provinsi Sumatera Barat.

3. Masih sedikit referensi tentang kekayaan daerah sebagai variabel independen.

\section{Saran}

Berdasarkan pembahasan dan kesimpulan dalam penelitian ini, maka peneliti mengajukan sran sebagai berikut:

\section{Bagi Pemerintah Daerah}

Diharapkan pemerintah daerah lebih memperhatikan faktor yang bisa meningkatkan belanja modal pemerintah daerah, supaya belanja modal bisa lebih ditingkatkan lagi, salah satunya dengan cara meningkatkan efisiensi belanja modal agar dipercepat penyaluran dan realisasinya.

\section{Bagi Penelitian Selanjutnya}

a. Diharapkan peneliti selanjutnya dapat menambah variabel-variabel lain dalam penelitian ini seperti PAD, Luas Wilayah dan pertumbuhan ekonomi untuk menguji pengaruh belanja modal. 
b. Diharapkan penelitian selanjutnya untuk dapat menambahkan sumber data yang digunakan maupun jangka waktu penelitian agar mendapatkan hasil yang lebih maksimal dan akurat.

\section{DAFTAR PUSTAKA}

Abdullah, S., \& Rona, R. (2014). Pengaruh Sisa Anggaran, Pendapatan Sendiri dan Dana Perimbangan terhadap Belanja Modal. Jurnal Iqtishadia.

Arifah, N. A., \& Haryanto. (2019). Analisis Pengaruh Sisa Anggaran, Pendapatan Asli Daerah dan Dana Perimbangan terhadap Belanja Modal di Kabupaten/Kota Provinsi Jawa Tengah tahun 2013-2017. Diponegoro Journal Of Accounting.

Budianto, \& Alexander, S. W. (2016). Pengaruh PAD dan Dana Perimbangan terhadap Kinerja Keuangan Pemerintah Kabupaten/Kota Provinsi Sulawesi Utara. Jurnal Emba: Jurnal Riset Ekonomi, Manajemen, Bisnis dan akuntansi.

Chaniago, F. (2019). Ranperda Pertanggungjawaban Pelaksanaan APBD Sumbar 2019, Fraksi DPRD Sorot Serapan Anggaran. http://padangmedia.com/ranperdapertanggungjawaban-pelaksanaan-apbd-sumbar-2019-fraksi-dprd-sorot-serapananggaran/.

Dewi, N. L., \& Dicriyani, N. L. (2018). Factors Affecting the Capital Expenditures in Bali Province. Journal Of Accounting and Strategic Finance.

Fahlevi, H. (2017). Revenue Budget Variance and Capital Expenditure Realization Emperical Evidence From Indonesian Local Government. Jurnal Dinamika Akuntansi.

Kusnandar, \& Siswantoro, D. (2012). Pengaruh Dana Alokasi Umum, Pendapatan Asli Daerah, Sisa Lebih Pembiayaan Anggaran dan Luas Wilayah terhadap Belanja Modal . Jurnal dan Prosiding SNA-Simposium Nasional Akuntansi.

Malau, E. I., Erlina, \& Sirojuzilam. (2019). The Effect of Local Goverment Revenue (LGR), Balance Fund, Capital Expenditure and Fiscal Stress on the Financial Performance of Regional Government in the District/City of Sumatera Utara Province. Jurnal Unsu.

Mentayani, I., \& Rusmanto. (2013). Pengaruh Pendapatan Asli Daerah, Dana Alokasi Umum dan Sisa Pembiayaan Anggaran terhadap Belanja Modal pada Kota dan Kabupaten di Pulau Kalimantan. Jurnal Infestasi Universitas Trunojoyo.

Mutiah, \& Mappanyuki, R. (2015). The Effect of Surplus Budget Financing, Special Allocation Fund, General Allocation Fund, Regional Revenue, and Characteristics of Local Goverment on Decision of Capital Expenditure . Research Journal of Finance and accounting.

Peraturan Menteri Dalam Negeri Nomor 21 Tahun 2011 tentang Pedoman Pengelolaan Keuangan Daerah.

Peraturan Presiden Nomor 5 Tahun 2010 tentang RPJMN tahun 2010-2014.

Peraturan Pemerintah Nomor 55 tahun 2005 tentang Dana Perimbangan.

Peraturan Pemerintah Nomor 71 Tahun 2010 tentang Standar Akuntansi Pemerintah.

Pratama, K. A., Werastuti, D. N., \& Sujana, E. (2015). Pengaruh Kompleksitas Pemerintah Daerah, Ukuran Pemerintah Daerah, Kekayaan Daerah, dan Belanja Daerah terhadap Pelaporan Keuangan Pemerintah Daerah. e-jurnal S1 AK Universitas Pendidikan Ganesha.

Rahayu, R. (2019). Pengaruh Sisa Anggaran, Pendapatan Sendiri dan Dana Perimbangan terhadap Belanja Modal. Jurnal Ilmu Ekonomi Terapan.

Rangkiang Data. http://sumbar.bpk.go.id/rangkiang-data/index.html.

Renas, \& Muid, D. (2014). Pengaruh Karakteristik Pemerintah Daerah dan Temuan Audit BPK terhadap Kinerja Pemerintah Daerah Kabupaten/Kota di Provinsi Jawa Tengah Periode 2009-2011. Diponegoro Journal Of Accounting. 
Sugiyanta. (2016). Analisis Belanja Modal dan Faktor-faktor yang mempengaruhinya pada Pemerintah Kabupaten/Kota di Indonesia. Jurnal Akuntansi Universitas Jember.

Sukarno, A., Hadioetomo, \& Haryadi, A. (2019). Analisis Faktor-Faktor yang Mempengaruhi alokasi Anggaran Belanja Modal. Journal Of Islamic accounting and Tax.

Sukmawati, R. (2016). Pengaruh Pendapatan Asli Daerah dan Sisa Lebih Pembiayaan Anggaran terhadap Belanja Modal pada Pemerintah Daerah Kabupaten. e-jurnal Bisma Universitas Pendidikan Ganesha.

Undang-Undang Nomor 32 Tahun 2004 Tentang Pemerintah Daerah.

Undang-Undang Nomor 33 Tahun 2004 Tentang Belanja Modal.

Undang-Undang Nomor 33 Tahun 2004 tentang Perimbangan Keuangan.

Widiasmara, A. (2019). Pengaruh Pendapatan Asli Daerah, Dana Alokasi Khusus, Dana Alokasi Umum, Total Aset dan Luas Wilayah terhadap Belanja Modal dengan Pertumbuhan Ekonomi sebagai Variabel Moderating. Journal Of Islamic Finance and Accounting.

Yolanda, F. (2017). Serapan Anggaran Sumbar Masih Lambat. http://m.republika.co,id/berita/nasional/daerah/17/08/22/ov364t370-serapananggaran-sumbar-masih-lambat. 